\author{
Asian Journal of \\ Medical and Biological Research \\ ISSN 2411-4472 (Print) 2412-5571 (Online) \\ www.ebupress.com/journal/ajmbr
}

\title{
Article \\ Growth and survival rate of Nandus nandus (Hamilton 1822) larvae on some selected supplemental feeds in cistern
}

\author{
Nilufa Begum ${ }^{1}$, Md. Mehedi Hasan Pramanik ${ }^{2}$ and Yahia Mahmud ${ }^{3}$ \\ ${ }^{1}$ Bangladesh Fisheries Research Institute, Brackishwater Station, Paikgacha, Khulna, Bangladesh \\ ${ }^{2}$ Bangladesh Fisheries Research Institute, Revarine station, Chadpur-3602, Bangladesh \\ ${ }^{3}$ Bangladesh Fisheries Research Institute, Head office, Mymensingh, Bangladesh
}

*Corresponding author: Nilufa Begum, Bangladesh Fisheries Research Institute, Brackish water Station, Paikgacha, Khulna, Bangladesh. E-mail: bfri.fpss@yahoo.com

Received: 06 March 2017/Accepted: 19 March 2017/ Published: 30 March 2017

\begin{abstract}
The aim of the investigation was to determine the effect of different food on growth and survival of Nandus nandus larvae. The experiment was conducted for 20 days in twelve (12) cisterns $(9 \times 6 \times 2.5 \mathrm{ft})$ to assess the effect of Zooplankton, Artemia, Tubifex and Brand Nursery Feed on growth and survival of N. nandus larvae in cistern condition. The growth of $N$. nandus larvae varied significantly $(\mathrm{P}<0.05)$ with live feed and artificial feed. Zooplankton treatment showed the best growth performance and Brand Nursery Feed showed the poorest. There was significant difference in final weight of larvae fed with live and artificial feed. Final weight of live feed Zooplankton was $241.79 \pm 17.25 \mathrm{~g}$, Artemia-210.37 $\pm 20.16 \mathrm{~g}$, Tubifex-226.36 $\pm 15.72 \mathrm{~g}$ and Brand Nursery Feedwas $195.08 \pm 15.53 \mathrm{~g}$ respectively. Specific growth rate $(\%)$ and percentage $(\%)$ weight gain were also best in case of Zooplankton fed $N$. nandus larvae. Different water quality parameters were more or less same in different treatments.
\end{abstract}

Keywords: Nandus nandus; mud perch; larvae; live feed; growth performance; zooplankton

\begin{abstract}
1. Introduction
The larval stage of any fish species is very important and sensitive for their life stage. Induced breeding remains ineffectual due to deficiency of proper feed. For this reason, it is indispensible to fix the proper larval feed. If unable to anticipate or develop the proper larval feed then it will be impossible to take alive the larvae. That why to anticipate larval feed, this work has been initiated. All though induced breeding success of this fish has been reported by a few workers (Begum et al., 2016; Pal et al., 2003; Rakhi et al., 2015) and no more works seems to have been conducted solves its larvae rearing and feeding problems. Nandus nandus (Hamilton, 1822) commonly known as mud perch which belongs to Nandidae family under Perciformes order, locally called Meni, Bheda, Rayna or Nondoi, is a small food eater fish in Bangladesh. International union for Conservation of nature IUCN Red List of Bangladesh (2015) has enlisted mottled that fish. N. nandus is in their red list of near threatened (NT) category fishes of Bangladesh.

Degraded aquatic ecosystem inhibits availability of $N$. nandus for this reason nursery development for promoting availability of $N$. nandus larvae is very essential. To develop nursery technologies, feed selection is prerequisite. It is a carnivorous fish and preys on small shrimps and fishes, insects larvae etc. (Mustafa et al., 1980). Predatory behavior was observed by Das and Zamal (2000).

Pal et al. (2003) reported that live food is superior in case of growth and survival rate of $N$. nandus fry to artificial feed. Successful technology of breeding and rearing will help to culture this fish in shallow waters like rice fields. Only $16 \%$ survival rate was calculated by feeding zooplankton that was observed by Pal et al. (2003). Therefore, development of nursing technology of $N$. nandus larvae will contribute not only national
\end{abstract}


economy but also help to protect $N$. nandus. The present study was conducted to evaluate the effect of selected feeds on growth and survival percentage (\%) of $N$. nandus in nursery system.

\title{
2. Materials and Methods
}

\subsection{Study aria}

This study was conducted at the hatchery complex in the campus of Bangladesh Fisheries Research Institute, Floodplain sub-station, Santahar, Bogra during 2011-2012.

\subsection{Stocking of larvae}

Twelve (12) cement cisterns $(9 \times 6 \times 2.5 \mathrm{ft})$ were used for the experiment. Time range was total 20 days. Five days old of $N$. nandus larvae produced by induced breeding technique using PG having an average initial length 0.50 $\mathrm{cm}$ and initial weight $4.13 \mathrm{mg}$ were stocked at the number of $1000 / \mathrm{m}^{3}$. Before stocking cotton cloth was inserted into cistern for spawn shelter due to adhesive behavior of $N$. nandus larvae. Water depth of each cistern was 1.25 fit. Continuous water flow was maintained in cisterns to make sure regular Oxygen circulation and proper water quality. Excess water passed out through an outlet after maintaining the mentioned volume of water.

\subsection{Treatment setup and preparation of different food}

After rearing for 5 days, four types of supplementary feeds were tested for larvae rearing. They were divided into 4 groups and separately fed with Zooplankton, Artemia, Tubifex and Brand Nursery Feed as treatment 1 $\left(\mathrm{T}_{1}\right)$, treatment $2\left(\mathrm{~T}_{2}\right)$, treatment $3\left(\mathrm{~T}_{3}\right)$ and treatment $4\left(\mathrm{~T}_{4}\right)$, respectively. There were three replications for each treatment.

\subsection{Zooplankton collection from ponds}

Zooplanktons were collected from ponds of Bangladesh Fisheries Research Institute, Floodplain sub-station, Santahar, Bogra by standard drop count method (APHA, 1995). Replicate plankton samples were collected by means of a bucket (50 litters) and filtered through bolting silk plankton net of $25 \mu$. In general, smallest size of the main zooplankton groups are rotifers and just-hatched copepods, are important first foods for larval fish (Ludwig, 1999) so, the plankton net mesh size were selected at $25 \mu$ for collection the smallest zooplankton as a feed of N. nandus.

\subsection{Tubifex Collection from natural source}

Tubifex were collected from natural source of Bangladesh Fisheries Research Institute, (BFRI), Floodplain Sub Station (FPSS) campus in Santahar, Bogra, Bangladesh.

\subsection{Artemia collection and re-capsulation}

Artemia were collected from feed market and re-capsulated in captive condition. Re-capsulation procedures were maintained properly.

\subsection{Nursery Brand Feed collection and proximate composition}

Three Brand Nursery Feed of three feed company were collected from feed market for proximate analysis by the method of Association of Official Analytical Chemists (AOAC, 1980) to detect the higher amounts of protein percent for treatment $\mathrm{T}_{4}$. Not only detecting the higher amounts of protein but another content percent also determined from the analysis. Another content were lipid, ash and moister.

\subsection{Determination of growth and survival}

The larvae were offered the feeds four times in a day by spreading method initially at the rate of 100,80 , and $60 \%$ of the total biomass of larvae for the first to last week's respectively. The dead fish were removed as soon as they were detected. Ten larvae of the stocked fish in each cistern were sampled at ten (10) days interval by using digital balance and graph paper. It was done in the morning before feeding. Length, weight, specific growth rate (\%), weight gain, Percent Weight gain $(\%)$ and survival rate $(\%)$ were analyzed and recorded. Following formulas were used to determine the growth performance.

\author{
a) Weight gain (mg): \\ Mean final weight - Mean initial weight \\ b) Percent weight gain $(\%)$ : \\ Mean final weight - Mean initial weight/Mean initial weight $\times 100$
}


c) Specific growth rate (SGR) (mg/day):

$\{\ln (\mathrm{FBW}=$ Final live body weight $(\mathrm{mg})-\ln (\mathrm{IBW}=$ Initial live body weight $(\mathrm{mg}) / \mathrm{D}=$ Number of days $\} \times 100$

d) Percent of Survival (\%):

(No. of fry alive / Total no. of fry stocked) $\times 100$

\subsection{Data analysis}

The Statistical data were analyzed by DMRT (Duncan's Multiple Range Test) with one-way analysis of variance (ANOVA). Difference levels of significance were considered at an alpha of 0.05 . It was performed by using SPSS statistical software package.

\subsection{Water quality measurement}

Physicochemical water quality parameters such as water temperature $\left({ }^{\circ} \mathrm{C}\right)$, dissolve oxygen $(\mathrm{mg} / \mathrm{l}), \mathrm{pH}$, total alkalinity $(\mathrm{mg} / \mathrm{l})$, and ammonia $(\mathrm{mg} / \mathrm{l})$ were analyzed on the same day of sampling. A centigrade thermometer measured temperature of water. HACH water test kit (Model-FF-2, USA) was used to measure $\mathrm{pH}$, dissolved oxygen (DO), total alkalinity, and ammonia $\left(\mathrm{NH}_{3}\right)$. Water quality of cistern was measured regularly.

\section{Results}

\subsection{Proximate composition of selected Nursery Brand Feed}

Higher amounts of protein-contained feed were used for treatment $T_{4}$. Proximate compositions of selected Brand Nursery Feed are shown in Table 1.

Table 1. Proximate composition of the Brand Nursery Feed.

\begin{tabular}{lll}
\hline Sl. No. & Item of Feed & Composition (\%) \\
\hline 1 & Protein & $34.88 \%$ \\
2 & Lipid & $15.99 \%$ \\
3 & Ash & $17.43 \%$ \\
4 & Moisture & $10.66 \%$ \\
\hline
\end{tabular}

\subsection{Determination of growth performance and survival}

The effect of food on growth and survival percent of $N$. nandus larvae was investigated in the present study. Four diets were tested during the period of 20 days feeding trial. At the termination of the feeding trial, it was observed that larvae fed with Zooplankton showed better growth and survival rate. The growth pattern and survival of $N$. nandus larvae fed with Zooplankton, Artemia, Tubifex, and Brand Nursery Feed is presented in Table 2.

Among all the treatments, $\mathrm{T}_{1}$ showed significantly highest $(\mathrm{P}<0.05)$ growth performance in weight $(241.79 \pm 17.25 \mathrm{~g})$, length $(2.02 \pm 0.28 \mathrm{~cm})$ and survival rate was $55 . \mathrm{T}_{4}$ showed lowest growth performance in weight $(195.08 \pm 15.53 \mathrm{~g})$, length $(1.46 \pm 0.07 \mathrm{~cm})$. Survival rate of $\mathrm{T}_{4}$ was 42 . The weight gain attained by the larvae of $T_{1}$ and $T_{3}$ were significantly better than $T_{2}$ and $T_{4}$. However, $T_{2}$ and $T_{4}$ were no significant difference ( $>0.05$ ) between the weight gain. In case of $\%$ weight gain, the larvae of $T_{1}$ and $T_{3}$ showed significantly better than $T_{4}$. There were no significant differences between $T_{1}$ and $T_{3}$ and between $T_{2}$ and $T_{4}$.

The Specific Growth Rate $\%$ of $\mathrm{T}_{3}$ and $\mathrm{T}_{4}$ had significant difference. Significantly $(\mathrm{p}<0.05)$ highest survival rate was showed in $T_{1}$ than those of $T_{2}$ and $T_{4}$. Survival rate of $T_{1}$ was highest.

Table 2. Mean $( \pm \mathrm{SD})$ growth performance of $N$. nandus spawn fed selected feeds for 20 days.

\begin{tabular}{|c|c|c|c|c|c|}
\hline Treatment & $\begin{array}{l}T_{1} \\
\text { Zooplankton } \\
\end{array}$ & $\begin{array}{l}\mathbf{T}_{2} \\
\text { Artemia }\end{array}$ & $\begin{array}{l}\mathbf{T}_{3} \\
\text { Tubifex }\end{array}$ & $\begin{array}{l}\mathbf{T}_{4} \\
\text { Brand Nursery Feed }\end{array}$ & $\begin{array}{l}\text { Level of } \\
\text { significance }\end{array}$ \\
\hline Initial length $(\mathrm{cm})$ & 0.50 & 0.50 & 0.50 & 0.50 & NS \\
\hline Initial weight (mg) & 4.13 & 4.13 & 4.13 & 4.13 & NS \\
\hline Final length $(\mathrm{cm})$ & $2.02 \pm 0.28^{\mathrm{b}}$ & $1.50 \pm 0.09^{\mathrm{a}}$ & $1.59 \pm 0.13^{\mathrm{a}}$ & $1.46 \pm 0.07^{\mathrm{a}}$ & $*$ \\
\hline Final weight (mg) & $241.79 \pm 17.25^{\mathrm{c}}$ & $210.37 \pm 20.16^{\mathrm{ab}}$ & $226.36 \pm 15.72^{\mathrm{bc}}$ & $195.08 \pm 15.53^{\mathrm{a}}$ & $*$ \\
\hline Weight gain (mg) & $237.66 \pm 17.25^{\mathrm{c}}$ & $206.24 \pm 20.16^{\mathrm{ab}}$ & $222.23 \pm 15.72^{b c}$ & $190.95 \pm 15.53^{\mathrm{a}}$ & $*$ \\
\hline$\%$ weight gain & 5754.48 & 4993.70 & 5380.87 & 4623.48 & - \\
\hline $\begin{array}{l}\text { Specific Growth } \\
\text { Rate }(\%)(\mathrm{mg})\end{array}$ & $20.35^{\mathrm{c}}$ & $19.64^{\mathrm{ab}}$ & $20.01^{\mathrm{bc}}$ & $19.28^{\mathrm{a}}$ & $*$ \\
\hline Survival rate $(\%)$ & $55^{c}$ & $47^{\mathrm{ab}}$ & $50^{\mathrm{bc}}$ & $42^{\mathrm{a}}$ & $*$ \\
\hline
\end{tabular}

$\mathrm{NS}=$ Means are not significantly different $(\mathrm{P}>0.05)$

* Mean values with different superscript letters in the same row indicate significant difference at $5 \%$ significance level. 


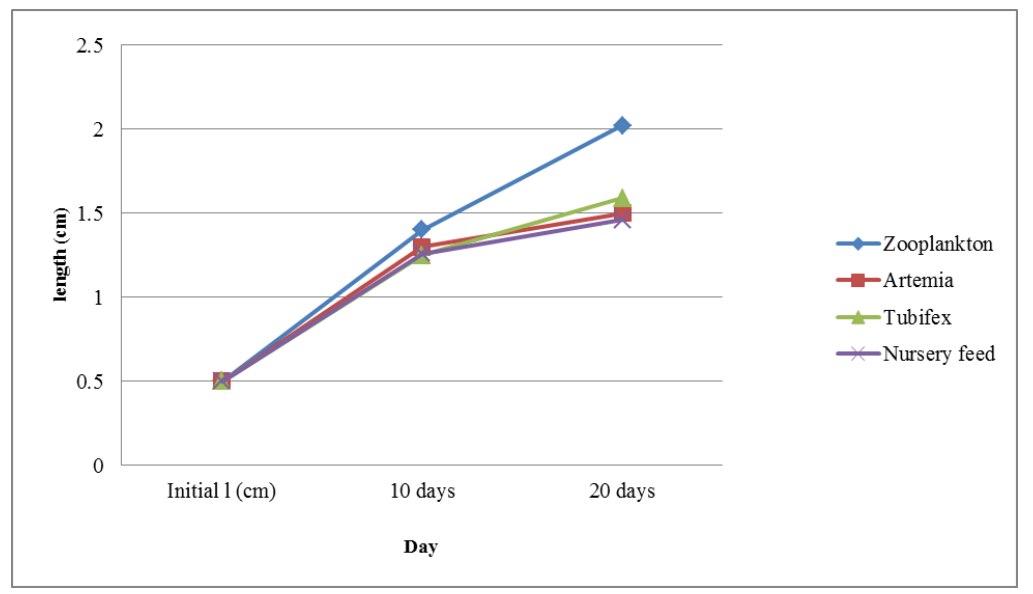

Figure 1. Mean length of $N$. nandus larvae in ten days interval under four treatments during the study.

\subsection{Water quality measurement}

The water quality parameters (Avg. \pm SD) values obtained from the four (4) cisterns are given in Table 3 . In the present study, the concentration of dissolved oxygen (DO) was found maximum in $T_{1}$ and minimum in $T_{2}$. Ammonia level was lowest in $\mathrm{T}_{1}$ and maximum in $\mathrm{T}_{4}$.

Table 3. Mean $( \pm \mathrm{SD})$ values of water quality parameters of different treatment.

\begin{tabular}{llllll}
\hline Treatment & $\begin{array}{l}\text { Temperature } \\
\left({ }^{\mathbf{0}} \mathbf{C}\right)\end{array}$ & $\mathbf{p H}$ & Total alkalinity & $\begin{array}{l}\text { Dissolve } \\
\text { Oxygen }(\mathbf{m g} / \mathbf{L})\end{array}$ & $\begin{array}{l}\text { Ammonia } \\
(\mathbf{m g} / \mathbf{L})\end{array}$ \\
\hline Zooplankton $\left(\mathrm{T}_{1}\right)$ & $28.60 \pm 0.15$ & $7.52 \pm 0.11$ & $189.73 \pm 2.10$ & $7.19 \pm 0.12$ & $0.08^{\mathrm{b}} \pm 0.01$ \\
Artemia $\left(\mathrm{T}_{2}\right)$ & $28.50 \pm 0.15$ & $7.41 \pm 0.12$ & $190.88 \pm 2.36$ & $7.07 \pm 0.08$ & $0.11^{\mathrm{a}} \pm 0.02$ \\
Tubifex $\left(\mathrm{T}_{3}\right)$ & $28.62 \pm 0.14$ & $7.24 \pm 0.07$ & $189.17 \pm 2.55$ & $7.10 \pm 0.14$ & $0.12^{\mathrm{a}} \pm 0.02$ \\
$\begin{array}{l}\text { Brand Nursery Feed } \\
\left(\mathrm{T}_{4}\right)\end{array}$ & $28.50 \pm 0.16$ & $7.51 \pm 0.07$ & $186.75 \pm 2.20$ & $7.19 \pm 0.13$ & $0.13^{\mathrm{a}} \pm 0.02$ \\
\hline Level of Significance & $\mathrm{NS}$ & $\mathrm{NS}$ & $\mathrm{NS}$ & $\mathrm{NS}$ & $*$ \\
\hline
\end{tabular}

$\mathrm{NS}=$ Means are not significantly different $(\mathrm{P}>0.05)$

* Mean values with different superscript letters in the same Colum indicate significant difference at 5\% significance level.

\section{Discussion}

The present study showed fed with live feed provided highest growth rate than artificial feed in case of carnivore fish was similar to Yasmin et al. (1998), Haque and Barua (1989). Islam et al. (2007) reported fed with artemia showed higher growth rate of $M$. gulio while fed with artificial feed gave poor growth and survival rate. Live food was better to growth and survival rate than ready feed because live food contained digestive enzyme and high protein, which were superior to growth of fish spawn. Alam and Mollah (1988) reported that C. batrachus larvae fed with live feed (Tubifex sp.) exhibiting significantly superior growth than artificial feed was similar to the present study. Aminul Islam et al. (1998) reported, C. batrachus showed better growth and survival was resemble to the present study, due to both species were carnivore. Kohinoor et al. (1999) stated Thai sharputi fed with live food showed lower growth than fed with formulated feed. It was occurred might be species variation and food habit variation. Pal et al. (2003) observed $N$. nandus larvae were fed with scrambled egg yolk, pasted tubifex worms, and zooplankton in duplicate aquaria. Only $16 \%$ survival rate was calculated by feeding zooplankton. No survival was observed among other food items. It was similar in case of feed type but dissimilar in case of survival rate to the present study.

Begum et al. (2016) found growth performance of $N$. nandus in nursery condition. It was $3.33 \pm 0.05 \mathrm{~mm}$ initial length and $0.81 \pm 0.03 \mathrm{mg}$ initial weight in releasing time, after 20 days of rearing it reached $21.02 \pm 0.24 \mathrm{~mm}$ length, $520 \pm 0.02 \mathrm{mg}$ weight and survival rate were $49.22 \%$. They have given $250 \mathrm{~g}$ wheat flour with six pieces boiled egg yolk, whichwas fed three times in a day (first three days). Fourth to sixth days $250 \mathrm{~g}$ wheat flour, six piece boiled egg yolk with nursery brand feed were provide two times in a day and rest of fourteen days $500 \mathrm{~g}$ wheat flour, $1 \mathrm{~kg}$ mustard oil cake with $2 \mathrm{~kg}$ cow dung were supplied as feed at alternative day. That experiment was based on increasing the plankton production in nursery pond for natural feeding of $N$. nandus larvae. 
Length measurement and survival percent is similar with Zooplankton $\left(\mathrm{T}_{1}\right)$ and Tubifex $\left(\mathrm{T}_{3}\right)$ but weight observation is dissimilar to the result of Begum $\mathrm{N}$ et al. (2016)'s observation. Probably natural condition and rearing technique was increasing the growth and survival (\%) of $N$. nandus in nursery pond and cistern (in this study) conditions by using the zooplankton.

Rakhi et al. (2015) observed that, after completing the embryonic stage, 50 days long experiment of $N$. nandus, supplementation of four type foods, only live tubificid worm shown highest growth and survival rate, which Length was $3.4 \pm 0.1 \mathrm{~cm}$ and weight $406.6 \pm 27.99 \mathrm{mg}$ and survival rate $97 \pm 1 \%$, where initial Length and weight were $1.25 \pm 0.08 \mathrm{~cm}$ and $38.8 \pm 7.96 \mathrm{mg}$. Survival rate of four treatments were live tubificid $97 \pm 1 \%$, Dry tubificid $78 \pm 2 \%, 1 \%$ DHA-73 $\pm 3 \%$ and Phospholipide $63 \pm 3 \%$ respectively. In this study of $25(5+20)$ days long growth experiment of $N$. nandus, $\mathrm{T}_{1}, \mathrm{~T}_{2}, \mathrm{~T}_{3}$ and $\mathrm{T}_{4}$ treatments result was similar with Rakhi et al. (2015) s experiment. In this study, Specific Growth Rate (\%) and Weight gain were highest. The day's differences were also double between two experiments. Though survival rates were better as reported by Rakhi et al. (2015) than this study.

The survival rate of $N$. nandus larvae $(55 \%)$ fed with Zooplankton $\left(\mathrm{T}_{1}\right)$ was significantly better than those reared with Tubifex $\left(\mathrm{T}_{3}\right)$, Artemia $\left(\mathrm{T}_{2}\right)$ and Brand Nursery Feed $\left(\mathrm{T}_{4}\right)$, which result was also similar to Islam et al., 2007.

Ludwig (1999) reported that, zooplankton is required as a first food for many cultured fish; for others it contributes to faster growth and higher survival and Copepod nauplii, which are just-hatched copepods, are important first foods for larval fish. In general, most of fish fries are taken three main types of zooplankton as food sach as rotifers, copepods and cladocerans (Ludwig, 1999; Morris and Mischke, 1999). Growth and survival rate of $N$. nandus larvae were higher in case of fed with zooplankton than other live foods.

Water quality parameter plays an important role in aquaculture. In this study ammonia level was significantly $(\mathrm{P}<0.05)$ lower in Zooplankton $\left(\mathrm{T}_{1}\right)$ treated water bodies. It may also reason for superior growth of $N$. nandus. Almost the physicochemical conditions of all treatments were good and provided an acceptable range for the growth and survival of $N$. nandus larvae.

\section{Conclusions}

Feed is essential for the growth of all animals. High quality feed provides superior growth and low quality of feed provides inferior. Feed selection is necessary to achieve better growth. $N$. nandus is carnivore, so it needs live food. Supplementary feed does not provide better growth rate in case of $N$. nandus larvae. Among all live feeds, Zooplankton shows higher growth. This research will help to indicate the suitable food for higher growth of $N$. nandus larvae. The results obtained from the present study and the discussion made so far, it is assistive to say that, the $N$. nandus larvae can be reared successfully fed with live zooplankton sp.

\section{Conflict of interest}

None to declare.

\section{References}

Pal S, H Rashid, MAK Tarafder, NT Narejo and M Das, 2003. First record of artificial spawning of Nandus nandus (Hamilton) in Bangladesh using carp pituitary gland: An endangered species bred in captivity. Pak. J. Biological Sciences., 6: 1621-1625.

Begum N, MMH Pramanik and Y Mahmud, 2016. Brood Development, Standardization of Hormone Dose and Larval Rearing of Endangered Species Meni (Nandus nandus). Int. J. Bus. Soc. Sci. Res., 4:146-151.

Hamilton F, 1822. Fishes of the Ganges. Archibald constable and company, Edinburgh., p. 96.

IUCN Bangladesh. Red List of Bangladesh Volume 5: Freshwater Fishes. IUCN, 2015. International Union for Conservation of Nature, Bangladesh Country Office, Dhaka, Bangladesh., p. 136

Mustafa G, ATA Ahmed and KR Islam, 1980. Food, feeding habits and fecundity of a fresh water perch, Menifish. Bangladesh J. Agric., 5: 205-210.

Das M, and N Zamal, 2000. Domestication of an endangered fish species Nandus nandus (Hamilton).Laboratory rearing of young fish up to sexual maturity. Bangladesh. J. Fish. Res., 4: 135-140.

APHA (American Public Health Association) 1995. Standard methods for the examination of water and waste water. 14th Ed., American Public Health Association. 1015 Eighteenth Street, N. W. Washington, D. C. 2036.

Ludwig GM, 1999. Zooplankton Succession and Larval Fish Culture in Freshwater Ponds. The Southern Regional Aquaculture Center, United States Department of Agriculture, Cooperative States Research, Education, and Extension Service. SRAC Publication No. 700. 
AOAC, 1980. Official methods of analyses of the Association of Official Analytical Chemists, Washington, D.C. USA.

YasminA, MFA Mollah, and GS Haylor, 1998. Rearing of cat fish (Clarias batrachus Lin.) larvae with live and prepared feeds. Bangladesh J. Fish.Res., 2: 145-150.

Haque MM and G Barua, 1989. Rearing of shingi(H. fossilis) fry under laboratory conditions-II. Feeding and growth of fry. Bangladesh. Fish., 12: 67-72.

Islam MA, M Begum, MJ Alam, HK Pal and MMR Shah, 2007. Growth and survival of estuarine catfish (Mystus gulio Ham.) larvae fed on live and prepared feeds. Bangladesh J. Zool., 35: 325-330.

Alam MS and MFA Mollah, 1988. Formulation of an artificial dry feed for primary nursing of cat fish (Clarias batrachus) larvae. Bangladesh J. Fish., 11: 71-75.

Aminul Islam M, M Badrudujahan and N Begum, 1998. Effects of different supplemental feed on the survival and growth of hybrid magur fry (C. batrachus C. gariepinus). Bangladesh J. Fish., 21:93-98.

Kohinoor AHM, MS Islam, N Begum and MG Hussain, 1999. Production of Thai sharpunti (puntiusgoniontus Bleeker) in polyculture with carps using low cost feed. Bangladesh J. Fish Res., 3: 157-164.

Rakhi SF, AHM Mohsinul Reza, M Shafaet Hossen and Z Hossain, 2015. Embryonic development and growth performances of an endangered fish species Nandus nandus: effects of dietary polyunsaturated fatty acids supplementation. Iranian Journal Fisheries Sciences., 14: 1029-1052.

Morris, Joseph E and CC Mischke, 1999. Plankton Management for Fish Culture Ponds. NCRAC Technical Bulletins., Paper 10. 